\title{
A CONTRIBUTION TO THE BRYOFLORA OF THE WESTERN GHATS IN KARNATAKA STATE, INDIA
}

\author{
UWE SCHWARZ \& JAN-PETER FRAHM ${ }^{1}$
}

\begin{abstract}
Based on fieldtrips of the authors in 2012, a list of species collected in a small area of the Western Ghats (Coorg District, state of Karnataka) is presented. It includes 18 species of liverworts and hornworts as well as 76 species of mosses. 27 species of mosses are newly reported for the state of Karnataka, 6 species are new for Coorg province. Holomitrium javanicum Dozy \& Molk. is reported as new to India. Campylopus sedgwickii Dix. described from Sri Lanka and so far only known from the type locality is a new synonym of C. recurvus Mitt. The list gives a rough inventory of the bryoflora in altitudes between $900 \mathrm{~m}$ and $1750 \mathrm{~m}$ and can be regarded as typical for the northern Western Ghats.
\end{abstract}

Key words: India, bryophytes, Holomitrium javanicum, Western Ghats

Uwe Schwarz, Prestige Grand Oak 202, 7th Main, 1st Cross, HAL IInd Stage, Indira Nagar, Bangalore 560038, India; e-mail: schwarzu@lumot.de

Jan-Peter Frahm, Bonner Str., 56, D-53424 Rolandseck, Germany; e-mail: frahmjp@googlemail.com

\section{INTRODUCTION}

The state of Karnataka is situated north of the states of Kerala and Tamil Nadu, which are known for their rich bryophyte flora and long history of bryological exploration. The species richness is due to the Western Ghats, a mountain ridge stretching NNW - SSE along the west coast of the Indian subcontinent.

Karnataka covers only a small portion of the Western Ghats and this might be the reason that this part is bryologically not as well known and the former bryological research focussed famous regions such as the Nilghiri Mountains, Palni Hills, Kodaikanal and others.

Although India is the tropical country with the most intensive bryological exploration, highest number of bryologist and highest rate of bryological publications, many regions remain to be studied and many bryophyte groups are in need of a taxonomical revision. The fact that Manju and Rajesh (2011) reported 13 species as new to India and 4 for Kerala State from a single nature preserve shows that the bryoflora of India is far from beeing explored.

\footnotetext{
1 Corresponding author
}

Therefore we as foreign bryologists take the opportunity to add the results of a collecting trip to a small region in the Western Ghats of Karnataka.

The collections are deposited in the herbaria of the authors (private herb. of Uwe Schwarz, hb. Frahm, BONN)

\section{THE STUDY AREA}

During the fieldtrip of the authors in November, 2012, only a small part of the mountain areas of Karnataka in the Coorg (Madikeri, Kodagu) District had been visited, which, however, seem to be typical and representative for the region. Coorg is the SW District of Karnataka bordering Kerala. The area is situated between $12.20^{\circ} \mathrm{N}$ and $12.22^{\circ} \mathrm{N}$ and $75.61^{\circ} \mathrm{E}$ and $75.67^{\circ} \mathrm{E}$, about $18 \mathrm{~km} \mathrm{WNW}$ of Virajpet (Fig. 1). A few additional locations have been visited along the road from Mysore to Madikeri, as well as from Madikeri to Virajpet. The highest point is Mt. Tadiandamol (1750 m). The study area (Fig. 2) covered the surroundings of Kabbe Holiday Resort and of Honey Valley 
Homestay. Both are situated within an extensive belt of coffee plantations in about $1000-1200 \mathrm{~m}$ altitude. The higher regions above $1200 \mathrm{~m}$ to the summit region in $1500 \mathrm{~m}$ are covered by open meadows and fragments of low forests. The lower, cultivated area bears a submontane bryoflora. Species number and abundance of bryophytes are increasing above $1000 \mathrm{~m}$ (lower montane belt) and another floristic change can be observed above $1200 \mathrm{~m}$. Open banks along the roads show a high variety of terrestrial species.

The area is drained by rivers flowing westwards comprising the Cauvery River and its tributaries. The closely located watershed to the east was not crossed.

The district enjoys a seasonal tropical climate with slight to medium humidity due to the proximity to the coast. Monsoon season starts in June and lasts till September, receiving a significant amount of rainfall till November. The dry season is characterized by cool temperatures until February and increasing temperatures until May.

The average temperature ranges between $19^{\circ}$ and $23^{\circ}$ degrees Celsius with rare extremes going up to $35^{\circ}$ and down to $9^{\circ}$ degrees.

The annual rainfall for the Coorg district is about $3500 \mathrm{~mm}$ with an average number of 118 rainy days per year. Misty weather in the morning during the cooler months contributes to the precipitation. Data indicating the difference of rainfall between the lower and upper areas are not available.

The soils of the district consist of lateritic debris found in different stages of laterization. Loamy soils, suitable for cultivation can only be found along the rivers. The area between Madikeri and Virajpet consists of granitic gneiss. Rock habitats are usually found along cliffs of the mountains, on isolated rocks in open areas and at the banks of streams and tracks.

\section{Map of Kodagu District Karnataka, India}

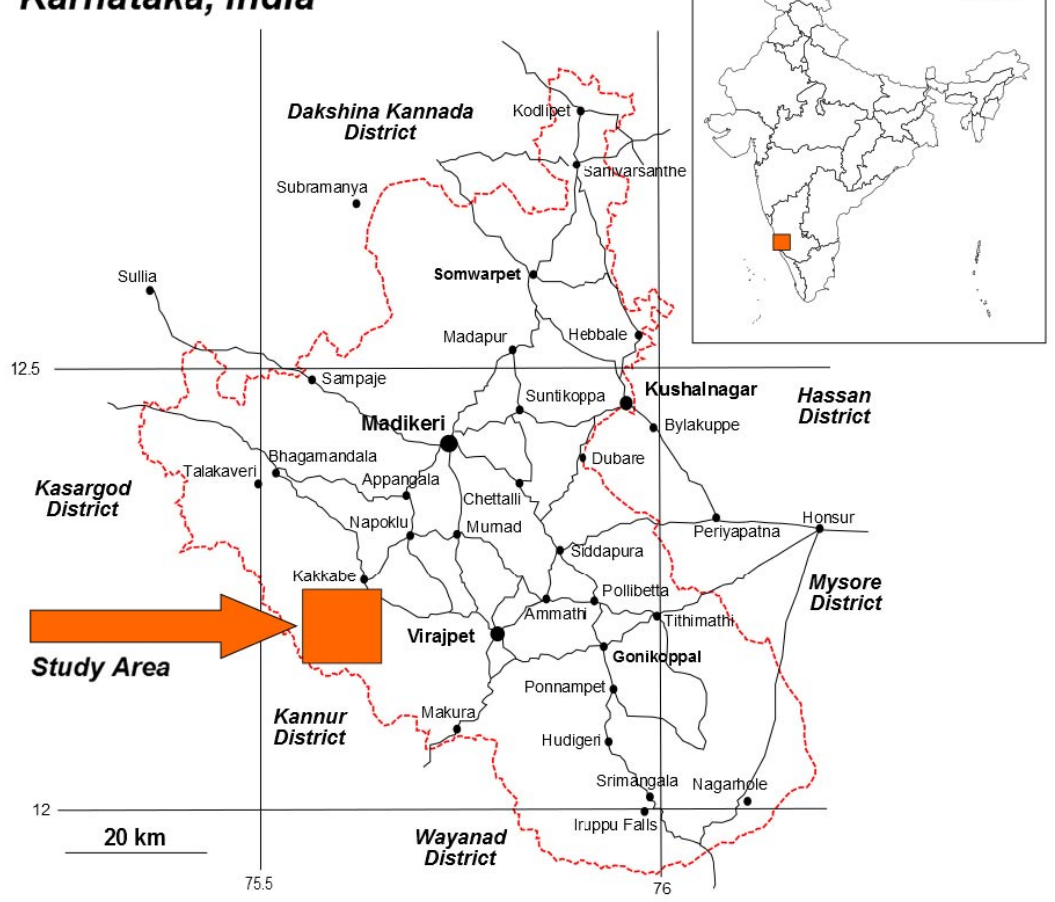

Fig. 1. Location of the study area within India and Coorg District. For detailed map see Fig. 2. 


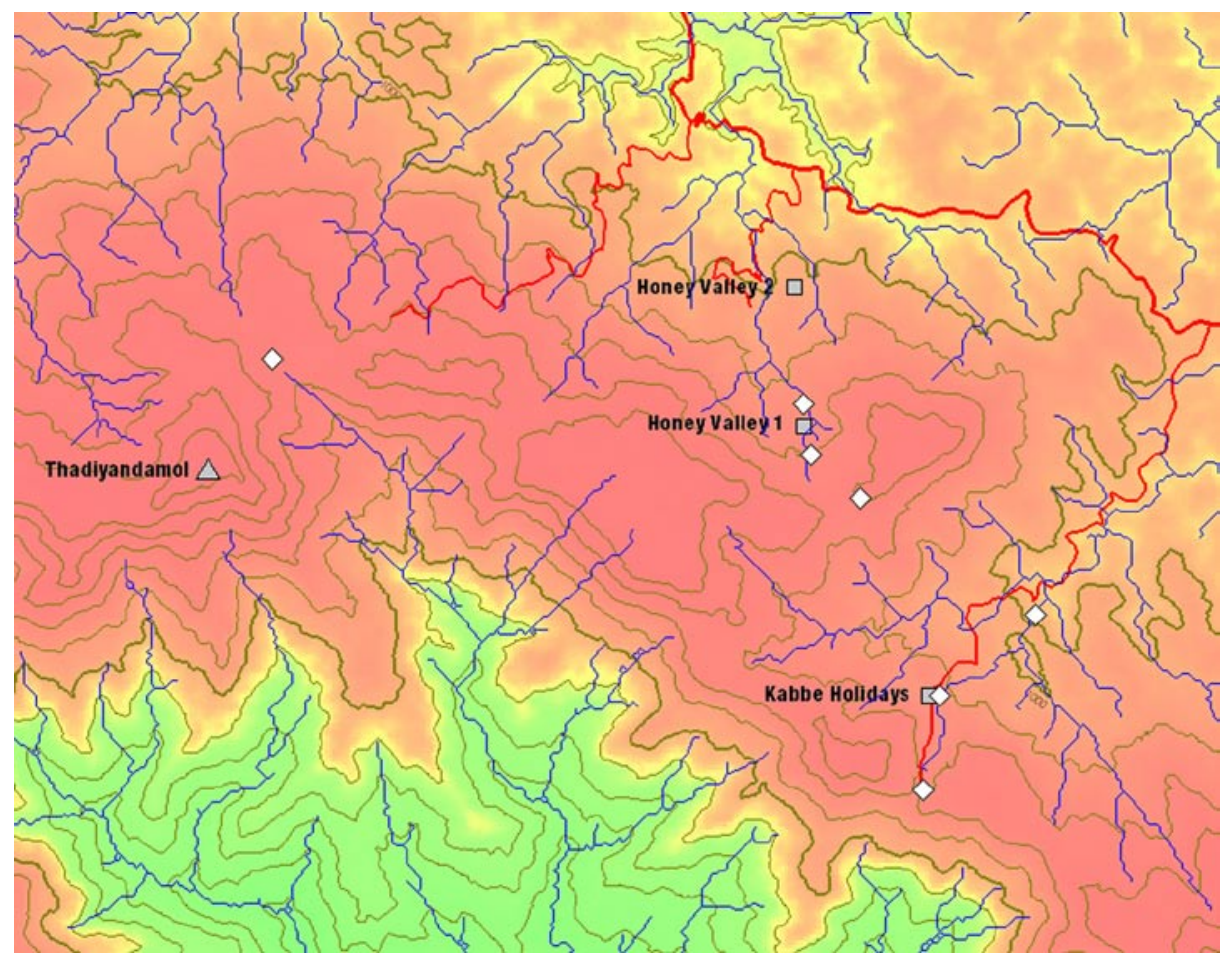

Fig. 2. Map of the study area. Dots - collection sites.

\section{STATE OF KNOWLEDGE}

Karnataka is a state of India for which no checklist was available till 2013, though there are checklists for the neighbouring states Kerala and Tamil Nadu. Therefore a first checklist of the mosses was compiled (Frahm et al. 2013) based on the few and scattered publications, which includes 152 species. Brotherus (1899) gave an account of mosses which were collected by T. L. Walker in 1897-1898 in the Coorg District. It includes records from Mt. Tadiandamol in our study area. Raghavan and Wadhwa (1968) gave an account of the mosses of the Agumbe-Hulical Ranges, which are located about $100 \mathrm{~km}$ north of the study area in Shimoga district. Results of a collection by L. J. Sedgwick, made in the Western Ghats about $300 \mathrm{~km}$ north to the study area were published by Dixon (1921). These three publications list altogether 144 moss species, subspecies and varieties. Entodon plicatus, Hyophila involuta, Leucoloma taylorii and Pele- kium velatum are mentioned in all three published sources. Both Brotherus (1899) and Raghavan and Wadhwa (1968) mentioned Brachymenium nepalense, Bryum argenteum, Cryptopapillaria fuscescens, Funaria hygrometrica, Macromitrium leptocarpum, M. sulcatum, Meteriopsis squrrosa, Octoblepharum albidum and Vesicularia reticulata. Townsend (1988) contributed to the bryoflora of Karnataka publishing the results of a smal collection from the Nandi Hills, approximately $100 \mathrm{~km}$ north of Bangalore. He reported 25 species that represent to a major degree species mentioned in the other publications.

General information on the bryoflora of India was obtained from the unpublished checklist of the bryophytes of India by Daniels, which gives no information on the distribution within India. A more recent checklist was published by Dandotiya et al. (2011), which includes distributional data, and lists all taxa reported from India including synonyms and not only the accepted names. 
Recent checklists regarding the Southern India were presented by Daniels (2010) for Tamil Nadu and Manju et al. (2008) for Kerala, summarizing the history of bryological exploration, all references and the geographical data. Additional data were provided by Verma and Srivastava (2011) on the endemism of liverworts of the Western Ghats, Verma et al. (2011) on the mosses of the Nilghiri Hills. Helpful for us was Manju et al. (2008), Manju et al. (2011) as well as Manju and Rajesh (2011), who provided inventories of nature preserves of Kerala, and Alam et al. 2011, who compiled a checklist of the mosses of Palni Hills, Tamil Nadu, which served as comparison for our study area.

\section{LIST OF SPECIES}

The specimens cited are kept in the herbaria of the authors. The list is far from being complete. Difficult groups such as Fissidens, Sematophyllaceae and many liverwort genera as well as Lejeuneaceae are under-represented due to the lack of appropriate literature for accurate species identification.

The symbols used in the text are as follows:

${ }^{* * *}$ New to India

** New to the state of Karnataka

* New to the province of Coorg

Photographs of many species were provided by Frahm (2013).

\section{Anthocerotophyta}

Phaeoceros laevis (L.) Prosk.

Frequent on roadside banks and open soil. The occurrence of Phaeoceros laevis subsp. carolinianus (Michx.) Prosk. has not been checked.

\section{Marchantiophyta}

Asterella wallichiana (Lehm. \& Lindenb.) Pandé et al.

Locally abundant on bare soil along trail banks in coffee plantations, on rocks of walls and on open soil in grassland together with Gongylanthus indicus and Entosthodon walli- chii. It is the most frequent thalloid liverwort in the area. The plants vary much in the width of the thalli and the thallus margins (narrow plants have a reddish border). The pseudoperianth is sometimes whitish, sometimes reddish, giving the impression of different species. The species is, however, distinguished from others of the genus by conical carpophor and dioicous sex conditions (Long 2006). Asterella khasiana (Griff.) Grolle is reported from the Western Ghats (e.g., Manju et al. 2009), which should have a flat carpophor. The differences between both were not clear, since young carpophors are hemiglobose and get flatter within the time.

\section{Cephaloziella kiaeri (Austin) S. W. Arnell}

Found intermixed with other bryophytes on soil and stone. The morphological diversity of plants from different collections indicates that the genus is represented by more than one species in the area.

\section{Chandonanthus birmensis Stephani}

Mt. Tandiandamol, on boulder in grassland with Herbertus dicranus.

Cololejeunea hasskarliana (Lehm. \& Lindenb.) Stephani

Mt. Tadiandamol, on common epiphyll liverwort in remnant forest. It seems to be less frequent at lower altitudes.

\section{Dumortiera hirsuta (Sw.) Nees}

Chingara Estate House, waterfall, on wet rocks beside a stream in 900 and $1000 \mathrm{~m}$.

\section{Frullania obscura (Sw.) Dumort.}

Kabbe Holiday Resort, trail to Mt. Kabbe, on small trees at the (planted) forest line at $1200 \mathrm{~m}$ (det. S. R. Gradstein).

Gongylanthus indicus S. C. Srivast. \& P. K. Verma

Kabbe Mt., on soil in open grazed bushland above $1000 \mathrm{~m}$. 
Herbertus dicranus (Taylor) Trevis.

Mt. Tandiandamol, on boulder in grassland with Chandonanthus birmensis.

\section{Jubula javanica Stephani}

Mt. Tandiandamol, $1680 \mathrm{~m}$, on rock in forest (det. S. R. Gradstein).

\section{Lejeunea flava (Sw.) Nees}

Common epiphyte to be found in almost all of the visited locations. It can easily be recognized by its yellowish green color and non glossy appearance.

\section{Lophocolea kurzii Sande Lac.}

Honey Valley, on rotten wood, resembling much L. heterophylla (Schrad.) Dumort.

Lophocolea muricata (Lehm.) Nees in Gottsche et al.

Mt. Tadiandamol, on shaded stone in remnant forest.

\section{Lopholejeunea subfusca (Nees) Schiffner}

Kabbe Mt., amongst other Lejeuneaceae on small tree at $1250 \mathrm{~m}$ (det. A. Schäfer-Verwimp).

Notoscyphus lutescens (Lehm. \& Lindenb.) Mitt.

Frequent along roadside banks.

\section{Pallacivinia levieri Schiffner}

Honey Valley, on buttress. The habitat on bark as well the male scales arranged in one row distinguish this species from P. lyellii (Hook.) Carruth. (Grolle \& Piippo 1986).

Spruceanthus cf. polymorphus (Sande Lac.) Verd.

Kabbe Valley, on rock (det. S. R. Gradstein).

\section{Targionia hypophylla $\mathrm{L}$.}

Honey Valley, Chingara, twice on trail banks in coffee plantations, much rarer than the common Asterella wallichiana. The thalli are conspicuously light green coloured (similar to Asterella) as compared with T. hypophylla from Europe, where it is dark blue green, and in appearance like Targionia lorbeeriana $\mathrm{K}$. Müller, but lacks the characteristic smell of the latter. Therefore it might be that $T$. hypophylla is generally lighter coloured in India or it is another species.

\section{Bryophyta}

${ }^{*}$ Actinodontium rhaphidostegium (C. Muelelr) Bosch. \& Lac.

Near Kabbe Holidays, on coffee trees and trunks of other trees in the valley. It is recognized by the spirally arranged, not complanate leaves and double costa.

Aerobryopsis longissima (Dozy \& Molk.) Fleisch.

Honey Valley and Kabbe Mt., scattered, pendant moss with short, very acute branches and long, fine, tortuose leaf point.

Anomobryum auratum (Mitt.) A. Jaeger

In the whole stuffy area. The linear thick walled upper laminal cells and the costa vanishing well below the apex identify the specimens as A. auratum (Ochi 1985). The plants vary much in size, they can be less than one or several centimetres. The species frequently grows on rocks and rocky trail banks.

Atrichum pallidum Renauld \& Cardot

Only once found on the way to Kabbe pass between grasses along the roadside. Atrichum aculeatum Card. \& P. de la Varde is synonymous (Nyholm 1971). The species can be recognized by its small laminal cells (about $18 \mu \mathrm{m}$ in diameter) and the low lamellae. Another species, Atrichum obtusulum (Müll. Hal.) A. Jaeger, is listed for India (Dandotiya et al. 2011). According to the Tropicos database (http://www.tropicos.org), it is a legitimate species, but not treated by Nyholm (1971).

${ }^{* *}$ Barbella bombycina (Ren. \& Card.) M. Fleisch.

Waterfall below Chingaara, Honey Valley, on stem. 


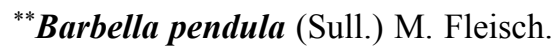

Kabbe Valley, pendant moss, recognized by flagelliform apices of branches.

Barbula indica (Hook.) Spreng.

Found on trail banks in Kabbe Valley

Brachymenium exile (Dozy \& Molk.) Sande Lac.

Kabbe Holiday Resort, on bare soil. The illustrations of the leaves of B. exile and B. acuminatum Harv. by Gangulee (1969-1972) look very similar, however, Ochi (1972) illustrates B. exile with long excurrent nerves and $B$. acuminatum with only percurrent nerves. The present specimens have a long excurrent arista.

\section{***Bachymenium longicolle Thér.}

Kabbe Valley and Honey Valley, on rocks and tree trunks. Similar to $B$. nepalense but with distinct apophysis. So far it is known from the Himalaya region.

\section{Brachymenium nepalense Hook.}

Kabbe Holiday Resort, on tree trunk. Brotherus (1899) lists B. nepalense as common from Coorg, which has an indistinct apophysis as compared with B. longicolle.

\section{Brachymenium sp.}

Chingara Estate House, walk to Manjamotte. The plants are large and robust, have long appressed foliate stems, $1 \mathrm{~cm}$ long or more, and lanceolate leaves with narrowly incurved leaf margins, with long setae up to $3 \mathrm{~cm}$ with erect or inclined cylindric capsule without apophysis. It grew on rock associated with Bryum wightii.

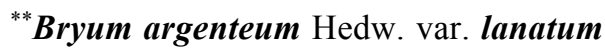 (P. Beauv.) Hampe}

Kabbe Holiday resort, on earth covered wall. This variety is characterized by the smaller size, the leaf tips curved outside and the occurrence in natural habitats, such as soil in open grassland. In contrast, the much 'fatter' $B$. argenteum var. argenteum with straight leaf apices is a nitrophilous species from urban environments.

\section{Bryum billarderi Schwaegr.}

This Bryum of sect. Rossulabryum looks a miniature Rhodobryum. It forms a complex of closely related species which was treated by Mohamed (1982). The species is frequent on humic soil and earth covered rocks in forests at all elevations.

\section{${ }^{* *}$ Bryum neelgheriense Mont.}

This species is related to B. billardieri but has filamentous gemmae in the leaf axils. It was collected once in Honey Valley. Walker collected the species in Coorg on dry clay banks near Virajpet [as B. ramosum (Harv.) Mitt.]. The species is treated in the $B$. billardieri complex (Mohamed 1979 ) as well in the $B$. wightii complex (Mohamed 1982), but seems to be related to B. billarderi in the same way as Bryum moravicum Podp. and $B$. capillare Hedw. in Europe.

\section{Bryum wightii Mitt.}

It is the most common species of Bryum in the study area. A very conspicuous large species, often more than $10 \mathrm{~cm}$, with conspicuous shining yellow-whitish-golden colour (according to Mohamed honey colour), which grows everywhere in exposed dry granite rocks in a typical association together with Campylopus recurvus and Macromitrium densum. Male plants were found once, however, no sporophytes. It can be identified using the work of Ochi (1985). As mentioned by the latter author, the species is very variable. The specimens are often gigantic for a species of Bryum, resembling Aulacomnium palustre (Hedw.) Schwaegr. Mohamed (1982) states that the size of the plants decreases from Ceylon northwards to India and that the specimens from the Western Ghats are usually smaller than the Ceylonese specimens. Thus, we cannot imagine how big the Ceylonese specimens will be. The size is in contrast to the dry habitat. Although Mohamed (1982) characterizes the habitat 'near wet areas 
such as waterfalls', which is not the fact in our study area, where the species grows on small rocks and large boulders mainly in grassland, and also on rocky outcrops, where it prefers temporarily seeping inclined rocks similarly to the habitat of Bryum alpinum Brid. (with which it seems to be related) in Europe.

\section{*Calymperes erosum Müll. Hal.}

Kabbe Valley on bark at lower altitudes, found often with Octoblepharum, rare, and not well developed. For a key to the southern Indian species of this genus, see Ellis (1989). The brood bodies are produced all around the excurrent costa and the teniolae stretch from the leaf base almost to the leaf tip.

\section{Calyptothecium wightii (Mitt.) M. Fleisch.}

On bark in the forest around Chelavara Falls.

Campylopus fragilis (Brid.) Bruch \& Schimp. subsp. goughii (Mitt.) J.-P. Frahm

On bark, rotten wood and rocks, the most common species of Campylopus in the study area in elevations above $1000 \mathrm{~m}$. For a revision of the Indian species, see Frahm (2012). The subspecies is recognized in the field by its small stature $(<2 \mathrm{~cm})$ and white shining leaf bases because of thin walled hyaline basal laminal cells. The upper laminal cells are short oval to oblique. The costa is very wide (more than half of the leaf width) and has large hyaline ventral hyalocysts, which may be also recognized without transverse section. The leaf is contracted at base. This species was known from India as $C$. goughii (Mitt.) A. Jaeger before, but belongs clearly to $C$. fragilis, from which it differs only by the shape of the upper laminal cells (oval instead of quadrate) and the costa not widened below the middle of the leaf. Campylopus fragilis subsp. fragilis has characteristic bunches of brood leaves in the axils of the upper leaves, which seem to lack in subsp. goughii, which has rarely short reduced branches or deciduous normal developed leaves as means of vegetative propagation. Another vicariant taxon, C. fragilis subsp. zollingerianus (Müll. Hal.) J.-P. Frahm, is found in Indonesia, which has shortly rectangular upper laminal cells instead of oval or quadrate ones.

\section{${ }^{*}$ Campylopus ericoides (Griff.) A. Jaeger}

Mt. Kabbe, Mt. Tandiandamol, on rocks $1200-1500 \mathrm{~m}$. This is a species difficult to recognize. It has subhyaline leaf tips, that means the excurrent costa can be shortly hyaline, almost hyaline or not. For that reason the species was listed in the Campylopus species of Sri Lanka (Frahm 1984) under two names, C. involutus (Müll. Hal.) A. Jaeger (with hair points ) and $C$. ericoides (without hair points). The name refers to the involute margins of the upper parts of the leaves. The upper laminal are oval and thus identical with $C$. schmidii. Problematical are also the basal laminal cells, which are rectangular and thick walled, although they can be thin walled (presumably in perichaetial leaves). Significant is the presence of side nerves, which are never found in C. schmidii, but in species of subg. Thysanomitrion, such as $C$. umbellatus. Characteristic is also the transverse section of the costa, which shows ventral subhyalocysts, that means the ventral cells are not enlarged but as large as the median deuter cells.

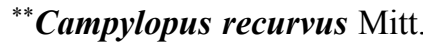

Mt. Kabbe, Mt. Tandiandamol, on rocks, boulders and outcrops, also on gravely soil in grassland at higher elevations above $1200 \mathrm{~m}$. This species is easily recognized by its blackish colour and recurved leaves with hyaline hair points. The upper laminal cells are oval and the basal ones subquadrate and thick walled and show a border of many rows of linear thin walled cells. This border can also cover the whole leaf base giving the impression of hyaline basal laminal cells. The alar cells are conspicuously protruding into the costa. Superficially, this species resembles Campylopus umbellatus in the blackish colour and oval upper laminal cells but differs by the recurved leaf apices and the transverse section of the costa with ventral 
hyalocysts and no ventral stereids. Campylopus sedgwickii Dix. described from Sri Lanka and so far only known from the type locality is a new synonym.

Campylopus recurvus (Mitt.) A. Jaeger, Ber. Thätigk. St. Gallischen Naturwiss. Ges. 1870-1871: 418, 1872. Campylopus sedgwickii Dix., J. Bot. 48: 303. 1910, syn. nov.

\section{${ }^{* *}$ Campylopus schmidii (Müll. Hal.) A. Jaeger}

Mt. Kabbe, on granitic outcrops at $1400 \mathrm{~m}$. Campylopus schmidii is an older name for C. aureus Bosch \& Sande Lac., a species widespread from Eastern Africa to Hawaii and India to northern Australia. It is a vicariant species of $C$. pilifer Brid. and differs from the latter only by the lack of lamellae at the back of the costa. As indicated by the collectors name, the type locality is in the Nilghiris. The species is characterized by oval upper laminal cells, rectangular thin-walled hyaline basal laminal cells, and the presence of hyaline hairpoints, which form pencil-like stem tips when well developed. Shade forms with reduced hairpoints are to distinguish from $C$. ericoides by hyaline thin-walled basal laminal cells. Both species can grow together in the same habitat. The plants are conspicuously golden-yellowish (cf., the name of $C$. aureus).

\section{Campylopus umbellatus (Arn.) Par.}

Mt. Kabbe, Mt. Manjamotte, Mt. Tandiandamol, on rocks at high altitudes. This is the most common species of Campylopus in SE Asia, where it grows in masses on rocks, typically along roadsides. The plants are usually blackish, the leaves have hairpoints and the stems have bud like perichaetia. In the study area, however, the species is dark green, has more often epilose or subepilose leaves and no perichaetia nor sporophytes. However, the species is recognized by the oval, pitted laminal cells, which are shortly rectangular and with a band of narrow hyaline cells only at the very base. The leaves are contracted at base and widest below the middle and show side nerves. The species was misnamed in India as $C$. richardii Brid. For details see Frahm (2012).

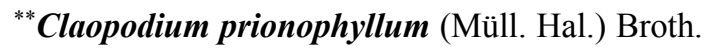

Waterfall below Chingaara, Honey Valley, on rocks along stream.

Cryptopapillaria fuscescens (Hook.) M. Menzel

Most frequent pendant moss in trees and bushes in the study areas.

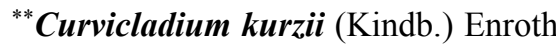

Honey Valley, on rock near stream. The species is recognized by an intramarginal border of elongate like Pinnatella alopecuroides, from which it differs by smaller stature, subdendroid branching and shorter intramarginal border. The leaves are conspicuously hooked in dry state. According to Gangulee (1969-1972) and Dandotiya et al. (2011), this species is Himalayan in distribution.

\section{Cyathophorum adianthum (Griff.) Mitt.}

On bark on Mt. Tandiandamol where Walker had collected this species already in 1898-1899 (Brotherus 1899).

\section{Daltonia sp.}

Mt. Kabbe, on twig. All species of the genus listed by Gangulee (1969-1972) and Dandotiya et al. (2011) are reported from the Himalaya region. The key in Gangulee does not allow a proper identification.

\section{Diaphanodon blandus (Harv.) Ren. \& Cardot}

Trail to Mt. Tandiandamol, Kabbe Mt., Honey Valley, base of tree and rocks. Diaphanodon procumbens is not included in Gangulee (19691972) and therefore it could not be decided whether the specimens might belong to the latter, which is mentioned by Dixon from Kanara.

\section{Ditrichum sp.}

Chingara Estate House, occasionally on vertical roadside banks with Pogonatum spp. etc. Ditrichum tortipes is the only species which Gangulee (1969-1972) reports from outside the Himalaya. Our collection is similar but the operculum ends 
in a longer beak. Dandotiya et al. (2011) list also D. amoenum (Thwaites \& Mitt.) Paris and D. difficile (Duby) M. Fleisch. from southern India.

${ }^{* *}$ Dixonia orientalis (Mitt.) H. Akiyama \& Tsubota

Forest below Mt. Tandiandamol, on rock (det. J. Enroth).

${ }^{* *}$ Entodon chloropus Renauld \& Cardot

Mt. Manjamotte, on rocks and branches.

\section{${ }^{*}$ Entosthodon wallichii Mitt.}

Everywhere frequent along roadside banks and on open soil in grass- and bushland. The species is characterized by the presence of a peristome, which, however, is easily detached that the capsules give the impression of an stegocarpous moss.

Fissidens sedgwickii Broth. \& Dix.

Kabbe valley, on rocks in stream (det. M. A. Bruggeman-Nannenga). The plants are $2 \mathrm{~mm}$ wide, stiff and rigid, not contorted when dry. The leaves have a bistratose dorsal lamina and the vaginant lamina gets bistratose towards the costa. Insofar the specimen resembles Pachyfissidens, in which the species was originally described.

\section{Floribundaria floribunda (Dozy \& Molk.)}

M. Fleisch.

Everywhere frequent on branches of trees and shrubs. The plants are very variable and can be small, only to $25 \mathrm{~mm}$ long and $1 \mathrm{~mm}$ wide, with acute or longely acuminate (unicellular) leaf tip. Therefore, it cannot be excluded that more species are hidden amongst the specimens, which needs, however, a more careful examination including the study of the types.

\section{Funaria hygrometrica Hedw.}

Kabbe Valley, on wall.

\section{Garckea flexuosa (Griff.) Marg. \& Nork.}

Everywhere on roadside banks and trail banks, also on open bare loamy soil with Trematodon spp., scattered or also in masses, often with immersed sporophytes.

Himantocladium cyclophyllum (Müll. Hal.)

M. Fleisch.

Kabbe Valley, on rock along stream (teste J. Enroth)

${ }^{* *}$ Himantocladium plumula (Nees) M. Fleisch.

Kabbe Valley, on rock along stream.

\section{****Holomitrium javanicum Dozy \& Molk.}

Honey Valley, walk to Manjamotte, on branch ca $1300 \mathrm{~m}$. The moss is conspicuous because of its flagellae in the axils of the upper leaves.

\section{${ }^{* *}$ Homaliodendron crassinervium Thér.}

On tree trunk in Honey Valley and Mt. Tandiandamol. This species has not yet been recorded outside the Himalaya, however, the taxonomy of the Indian representative of this genus needs clarification, since Dandotiya et al. (2011) do not have the species in their checklist. It seems to be characterized by relative small $(1 \mathrm{~mm})$ branch leaves, which are very short $(1: 2)$ and extremely long serrate leaf tips.

${ }^{* *}$ Homaliodendron exiguum (Bosch. \& Sande Lac.) M. Fleisch.

Found on bark at Mt. Tadiandamol, as well as on rotten wood in a small ridge along the way between Madikeri and Virajpet. The obtuse leaves make it easily distinguishable from the other species of the genus.

Homaliodendron flabellatum (Sm.) M. Fleisch.

Chingara Estate, in coffee plantation.

\section{Hyophila involuta (Hook.) A. Jaeger}

A pantropical species, usually growing in masses on rocks and concrete walls. Brotherus (1899) mentioned this species, but $H$. cylindricarpa (Hook ex Harv.) A. Jaeger from much more 
collections, which has not been observed by the authors in the area.

\section{${ }^{* *}$ Hypopterygium tamarisci (Besch.) Kindb.}

Mt. Tandiandamol; waterfall behind pass above Honey Valley, scattered on rocks, rotten wood and base of tree trunks $1000-1650 \mathrm{~m}$. The plants are of variable size and can sometimes be minute (' $H$. tenellum'), however, all intergradations can be observed in the field. Hypopterygium tamarisci is a pantropical species and was described under 81 (!) different names (Kruijer 2002). Dandotiya et al. (2011) listed five species from India, of which $H$. aristatum Bosch \& Sande Lac. is a synonym of $H$. flavolimbatum Müll. Hal. and $H$. tenellum Müll. Hal. is synonymous with H. tamarisci. Hypopterygium pachyloma Dix. ex R. S. Chopra recorded from W. Bengal belongs to Dendrohypopterygium arbuscula (Brid.) Kruijer. Thus, only two but not five species are present in India. The second species in India, H. flavolimbatus, grows in India only at the flanks of the Himalayas and differs by leaves arranged in eight, not three rows.

${ }^{* *}$ Leucobryum juniperoideum (Brid.) Müll. Hal.

Mt. Tandiandamol, on tree trunk.

\section{${ }^{* *}$ Leucoloma amoene-virens Mitt.}

Everywhere frequent on tree trunks. In appearance, it is like a species of Campylopus, but with narrow costa and leaf margin of hyaline cells. It is the only representative of the genus in the area.

\section{${ }^{* *}$ Macromitrium densum Mitt.}

Everywhere on rocks in open habitats. The plants are characterized by blunt lingulate leaves and short ovoid to almost round capsules. It is only half the size of M. sulcatum. Gangulee (19691972) indicates this species only from Nepal.

\section{Macromitrium moorcroftii Schwaegr.} Falls.

Only found once on bark near Chelavara

\section{Macromitrium sulcatum Brid.}

By far the most common Macromitrium species in the study areas. It grows mostly on bark but can also found on stone and rarely on soil. The hyaline group of cells in the middle of the leaf base with adjacent papillose, rectangular cells and the lanceolate leaf shape distinguish it from all other species.

\section{Macromitrium sp.}

Mt. Kabbe. This peculiar species was found occasionally on stone. Its circular, mamillose cells that create trigones in the cell angles are most characteristic.

Meteoriopsis reclinata (Müll. Hal.) M. Fleisch.

A common epiphyte in the study areas. The species name refers to the squarrose leaves.

\section{${ }^{*}$ Microdus brasiliensis (Duby) Thér.}

Trail to Mt. Kabbe, occasionally on bare soil, associated with Garckea flexuosa and Trematodon longicollis. Easy to recognize by the Dicranella like appearance of the plant and the almost globose capsules without peristome.

\section{Microcampylopus khasianus (Mitt.) Giese \& Frahm}

Once found in masses on soil of a trail E of Kabbe Pass. The checklist by Dandotiya et al. (2011) lists five species [Campylopodium griffithii (Mitt.) Mitt. ex Broth., C. khasianus (Griffiths) Paris, C. phascoides (Müll. Hal.) Paris, as well as Microcampylopus khasianus and M. subnanus (Müll. Hal.) Broth.], which are all identical with this species (Frahm 2012). The lack of stomata in the capsules clearly proves that it is a species of Microcampylopus, not Campylopodium.

Octoblepharum albidum (Hedw.) Mitt.

A pantropical species in the study areas on tree trunks at elevations below $1000 \mathrm{~m}$ altitude, usually in small quantities. 
${ }^{* *}$ Oxystegus tenuirostris (Hook. \& Tayl.)

A. J. E. Smith

Kabbe Valley, on rocks in shady habitats. Oxystegus cylindricus (Bruch ex Brid.) Hilp. (Dandotiya et al. 2011) is not a separate species but a synonym.

\section{Philonotis mollis (Dozy \& Molk.) Mitt.}

Everywhere on soil and rocks along roadsides. The plants are only $1 \mathrm{~cm}$ tall, although described by Gangulee as more than $2 \mathrm{~cm}$, but fit the species description in other respects. They can be recognized by the blue-green colour of the leaves, which are very lax and distant along the stem.

\section{Philonotis thwaitesii Mitt.}

Kabbe valley, on wet vrock in coffee plantation. In contrast to the previous species, these plants are densely foliate with a thick tomentum and have leaves with strongly involute leaf margins.

Pinnatella alopecuroides (Mitt.) M. Fleisch.

On tree trunk in Honey Valley.

** Pinnatella kurzii (Kindb.) Wihj \& Marg.

On tree trunk in Honey Valley.

\section{${ }^{*}$ Pinnatella limbata Dix.}

Waterfall below Chingaara House, on rock in stream (det. J. Enroth). This species was described by Dixon (1921) from Karnataka, and reportedly known from only one additional collection (see Enroth 1994) and is therefore regarded as critically endangered (J. Enroth, pers. com.), but the species has been collected several times in the area by the authors. A special publication by the first author dealing with the status of this species is under preparation. The name refers to the bistratose leaf border.

\section{Pogonatum neesii (Müll. Hal.) Dozy}

Common on roadside banks in the study areas. Hyvönen (1989) calls it the most common species of the genus in SE Asia. It has somewhat flattened lamellae, which is papillose according to Hyvönen (1989), which is not the fact in our specimens. Pogonatum neesii is commonly treated as forma of $P$. aloides (Hedw.) P. Beauv. in the Indian literature, which is not the fact. Hyvönen (1989) writes: 'In the past, Pogonatum aloides has also been repeatedly been confused with the Asian $P$. neesii. The two species are very similar in that both have leaves curved in dry condition, and they have numerous teeth on the dorsal side of the wide costa. P. neesii is more variable in size, while $P$. aloides is almost always a plant with fairly short stems'.

\section{** Pogonatum patulum (Harv.) Mitt.}

Honey Valley, Kabbe Valley. This is a minute species on bare soil of roadside banks. Eighteen species of Pogonatum have been so far reported from India (Dandotiya et al. 2011). The revision of the genus (Hyvönen 1989) cites only half the number for India. Four of them [P. urnigerum (Hedw.) P. Beauv., P. microstomum (R. Br. ex Schwägr.) Brid., P. fastigiatum Mitt., P. nudiusculum Mitt.] are large plants and Polytrichum-like species of higher altitudes. P. proliferum (Griff.) Mitt. has almost no lamellae, and P. perichaetiale (Mont.) A. Jaeger has strongly incrassate terminal cells of lamellae.

${ }^{* *}$ Pterobryopsis conchophylla (Renauld \& Cardot) Broth.

Epiphytic in Honey Valley. The species has conspicuous flagellae. It is recognized by dendroid to subdendoid habit, ovate, concave leaves abruptly acuminate into a short point, quadrate alar cells, and costa reaching $2 / 3$ of leaf length.

\section{${ }^{* *}$ Pterobryopsis flexipes (Mitt.) M. Fleisch.}

Epiphytic, rarely in Kabbe valley and ridge trail above Honey Valley.

\section{${ }^{* *}$ Pterobryopsis gedehensis M. Fleisch.}

Common and widespread on trees. The plants are very robust and have conspicuous flagellae similar to $P$. conchophylla, however, the costa is small and double and does not reach midleaf, like 
the latter. The leaves are orbicular and very concave with a cucullate apex and abruptly narrowed in a fine long point. Although not reported from Karnataka before and not included in Gangulee (1969-1972), the species is quite frequent in the region. Of the six species (incl. Pterobryon) reported from Karnataka, only three are described and illustrated by Gangulee (1969-1972), who includes three more species from the Himalayas. Dandotiya et al. (2011) list twelve species in the genus for India.

Pterobryopsis tumida (Dix. ex Hook.) Dix.

Common epiphyte or pendant robust moss, frequent on tree trunks in all altitudes.

Racopilum cuspidigerum (Schwägr.) Ångstr.

Common and frequent on stones and walls. Dandotiya et al. (2011) listed four species $[R$. cuspidigerum, $R$. intermedium Hampe, $R$. orthocarpum Wils. ex Mitt. and R. schmidii (Müll. Hal.) Mitt.], while Gangulee (1969-1972) only two (R. cuspidigerum and $R$. orthocarpum Wilson ex Mitt.), which the latter differentiates by the position of the capsule (inclined viz. erect), although sporophytes were not found in India.

\section{Racopilum sp.}

We collected two species, a larger one with acute leaves and serrate leaf margins and a smaller one with obtuse leaf tips with smooth or finely crenulate margins. The first is attributed to R. cuspidigerum as compared with the illustration in Gangulee (1969-1972). We have no name for the second one. Since Gangulee describes and illustrates $R$. orthocarpum with serrate leaf margins, the unknown species could be $R$. schmidii. This is supported by the fact that Müller described (Botanische Zeitung 1854: 558) the leaves as oblong with crenulate margins. However, Van Zanten (2006) placed $R$. schmidii as a synonym to $R$. cuspidigerum.

\section{Rhodobryum giganteum (Schwaegr.) Paris}

On rocks, only at Mt. Tadiandamol in $1650 \mathrm{~m}$ altitude. The species looks similar to $R h$. roseum
(Hedw.) Limpr., which is only a bit smaller but has single teeth, whereas $R h$. giganteum has the teeth in pairs.

Schoenobryum concavifolium (Griff.) Gangulee

Honey Valley, on coffee trees.

\section{${ }^{* *}$ Symphysodontella tortifolia Dix.}

Kabbe valley, in coffee plantation, a conspicuous dendroid epiphyte.

${ }^{* *}$ Thamniopsis utacamundiana (Mont.) W. R. Buck

On rocks in the forest below the summit of Mt. Tadiandamol. The plants are conspicuously reddish.

\section{${ }^{* *}$ Thuidium cymbifolium (Dozy \& Molk.) Dozy} \& Molk.

Mt. Tadiandamol at $1650 \mathrm{~m}$, on rocks and fallen tree trunks. It's one of the frequent Thuidium species in the area that was found around the homestays at $1100 \mathrm{~m}$ up the remnant forests.

\section{** Thuidium orientale Mitt. ex Dix.}

Kabbe Valley, on rock beside stream. Recognized by the spinose back of the costa.

\section{Trachypodopsis serrulata (P. Beauv.) Besch.}

Kabbe Valley, occasionally on rocks in coffee plantation.

\section{Trematodon longicollis Michx.}

Kabbe Valley and Honey Valley, occasionally on soil banks, sometimes in masses. A pantropical species which is often reported in the Indian bryological literature, although Chopra (1975) does not recognize it. The species can be recognized by the long column, which is about three times as long as the urn. The size of the plants varies much, small plants with shorter setae give the impression of a separate species but have the same spore size and ornamentation. 


\section{Trematodon sp.}

On soil bank at Kabbe Resort. The plants are minute and the urn is of about the same length as the column.

Trichosteleum monostictum (Thwaites \& Mitt.) Broth.

On rotten wood in a remnant forest at Mt. Tadiandamol. This species was already reported by Brotherus (1899) from the same location. Trichosteleum stigmosum Mitt. that was recently reported by Manju et al. (2012) from Kerala shows a close resemblance to T. monostictum. Both species are closely related to T. boschii (Dozy \& Molk.) A. Jaeger and should be studies in more detail in future.

\section{Weissia edentula Mitt.}

Honey Valley, on roadside banks and trail banks, also on open bare loamy soil. It is quite often associated with Garckea flexuosa and Philonotis species. All the collections bear sporogons that make it easy to distinguish it from other Pottiaceae.

ACKNOWLEDGEMENTS. The authors like to thank Ida Bruggeman-Nannenga, Johannes Enroth, S. Robbert Gradstein and Alfons Schäfer-Verwimp for identification of specimens.

\section{REFERENCES}

Alam A., P. K. Verma, G. Asthana \& S. YadaV 2011. Moss Flora of Palni Hills (Tamil Nadu), India - A Checklist. Archive for Bryology 112: 1-8.

BROTHERUS V. F. 1899. Report on a collection of mosses made by Dr. T. L. Walker in Coorg during the cold wheather of 1897-98. Rec. Bot Surv. India 1: 311-329.

ChOPRA R. S. 1975. Taxonomy of Indian Mosses. Publications \& Information Directorate, Council of Scientific \& Industrial Research, New Delhi.

DANDOTIYA D., GOVINDAPYARI H., SUMAN S. \& UNIYAL P. L. 2011. Checklist of the bryophytes of India. Archive for Bryology 88: 1-126.

DANIELS A. E. D. 2010. Checklist of the Bryophytes of Tamil Nadu, India. Archive for Bryology 65: 1-117.
DiXON H. N. 1921. On a collection of Mosses from the Kanara District. J. Indian Bot. 2: 174-188+ 1 plate.

ELLIS L. T. 1989. A taxonomic revision of Calymperes in southern India and neighbouring islands. J. Bryol. 15: 697-732.

ENROTH J. 1994. A taxonomic monograph of the genus Pinnatella (Neckeraceae, Bryopsida). Acta Bot. Fenn. 151: $1-90$.

FRAHM J.-P. 1984. A survey of the genus Campylopus in Sri Lanka. J. Bryol. 13(2): 163-192.

Frahm J.-P. 2012. A revision of the Campylopodioideae (Musci, Dicranaceae) from India. Archive for Bryology 150: $1-5$.

FRAHM J.-P. 2013. The mosses and liverworts of the Western Ghats of Karnataka (India) - a picture book. Archive for Bryology Special Volume 14: 1-60.

FRAHM J.-P., SCHWARZ U. \& NAIR M. 2013. A checklist of the mosses of Karnataka, India. Archive for Bryology 158: $1-15$.

GANGULEE H. C. 1969-1972. Mosses of Eastern India and Adjacent Regions, 1-3. Published by the author, Calcutta.

Grolle R. \& PiIPpo S. 1986. Bryophyte Flora of the Huon Peninsula, Papua New Guinea, XVI. Acta Bot. Fenn. 133: 59-79.

Hyvönen J. 1989. A synopsis of genus Pogonatum (Polytrichaceae, Musci). Acta Bot. Fenn. 138: 1-87.

KRUIJER H. 2002. Hypopterygiaceae of the world. Blumea, Suppl. 13: 1-388.

LONG D. G. 2006. Revision of the Genus Asterella P. Beauv. in Eurasia. Bryophyt. Biblioth. 63: 1-299.

MANJU C. N. \& RAJESH K. P. 2011. Contribution to the bryophyte flora of India: the Parambikulam Tiger Reserve in the Western Ghats. Archive for Bryology 92: 1-10.

MANJU C. N., RAJESH K. P. \& MADHUSOODANAN P. V. 2008. Checklist of the bryophytes of Kerala, India. Tropical Bryology Research Reports 7: 1-24.

MANJu C. N., RAJESH K. P. \& MADHUSOOdANAN P. V. 2009. Contribution to the bryophyte flora of India: the Aralam Wildlife Sanctuary in the Western Ghats. Archive for Bryo$\operatorname{logy}$ 42: 1-12.

Manju C. N., Prakashkumar R., Prajitha B., Rajilesh V. K. \& ANNOP K. P. 2012. Trichosteleum stigmosum Mitt. (Sematophyllaceae) from Silent Valley National Park, a New Record for India. Taiwania 57: 222-224.

Manju C. N, Rajesh K. P., Jitha S., Reshma P. K. \& PraKASHKUMAR R. 2011. Bryophyte diversity of Kakkavayal Reserve Forest in the Western Ghats of India. Archive for Bryology 108: 1-7.

MOHAMED H. 1979. A taxonomic study of Bryum billardieri Schwaegr. and related species. J. Bryol. 10: 401-463. 
Mohamed H. 1982. Bryum wightii Mitt. and related species. J. Bryol. 12: 23-29.

Nyнolm E. 1971. Studies in the genus Atrichum P. Beauv., a short survey of the genus and the species. Lindbergia 1: $1-33$.

OCHI H. 1972. A revision of African Bryoideae, Musci (First Part). J. Fac. Educ. Tottori Univ. Nat. Sci. 23: 1-122.

OCHI H. 1985. An annotated list of the mosses of the subfamily Bryoideae in South, Southeast and East Asia. J. Fac. Educ. Tottori Univ. Nat. Sci. 34(2): 41-96.

Ragavan R. S. \& Wadhwa B. M. 1968. Mosses of AgumbeHulical Ranges, Shimoga District. Bull. Bot. Surv. India 10: $344-347$.
TownsEND C. C. 1988. Mosses from the Nandi Hills, Mysore State, India. J. Bryol. 15: 289-291.

Verma P. K. \& SRIVASTAVA S. C. 2011. Endemism in liverworts of Western Ghats and their present status. Archive for Bryology. 99: 1-23.

Verma P. K., Alam A. \& SRivastava S. C. 2011. Status of mosses in Nilgiri Hills (Western Ghats), India. Archive for Bryology 102: 1-16.

ZANTEN B. O. VAN 2006. A synoptic review of the Racopilaceae (Bryophyta, Musci). 1. Asian, Pacific and Australasian species of the genus Racopilum. J. Hattori Bot. Lab. 100: 527-552.

Received 17 April 2013 